218 с. 9. Карпенко Ю. А. Потебня А. - зачинатель українського народознавства / Ю. А. Карпенко // Філософська і соціологічна думка. - 1995. - №1-2. - С. 27-29. 10. Колесников А. А. Языковая ситуация в Придунайском крае Одесской области Украины / А. А. Колесников, Е. П. Берестецкая и др. - Измаил, 1994. - 39 с. 11. Макеев С. А. Подвижность структуры. Современные процессы социальной мобильности / С. А. Макеев, И. М. Прибыткова. - Київ, 1999. - 116 с. 12. Методологія, теорія і практика соціологічного аналізу сучасного суспільства : [зб. наук. праць]. - Харків, 2002. - 621 с. 13. Потебня А. А. Эстетика и поэтика / А. А. Потебня. - Москва, 1976. - 612 с. 14. Сепир Э. Коммуникация / Э. Сепир // Избранные труды по языкознанию и культурологии. - Москва, 1993. - 656 с. 15. Сорокин П. Человек. Цивилизация. Общество / П. Сорокин. - Москва, 1992. - 543 с. 16. Соссюр Ф. Труды по языкознанию / Ф. де Соссюр. - Москва, 1977. - 695 с. 17. Швейцер А. Д. Введение в социолингвистику / А. Д. Швейцер, Л. Б. Никольский. Москва, 1978. - 216 с.

\title{
ДИДАКТИЧНИЙ РЕСУРС ЕЛЕКТРОННОГО СЕРЕДОВИЩА В ОРГАНІЗАЦІЇ САМОСТІЙНОЇ РОБОТИ МАЙБУТНІХ УЧИТЕЛІВ ПОЧАТКОВИХ КЛАСІВ
}

Нагрибельна I. А. Дидактичний ресурс електронного середовища в організації самостійної роботи майбутніх учителів початкових класів.

У статті проаналізовано науково-методичний потенціал дидактичного ресурсу електронного середовища. Акцентовано увагу на його ролі в організації самостійної роботи майбутніх учителів початкових класів, з'ясовано сутність дефініцій, що стосуються до інформаційно-навчального середовища у сучасному виші.

Ключові слова: інформаційно-навчальне середовище, електронне середовище, дидактичний ресурс, самостійна робота.

Нагрибельная И. А. Дидактический ресурс электронной среды в организации самостоятельной работы будущих учителей младших классов.

В статье проанализирован научно-методический потенциал дидактического ресурса электронной среды. Акцентируется внимание на его роли в организации самостоятельной работы будущих учителей младших классов, определена суть дефиниций, которые имеют отношение к информационно-обучающей среде в современном высшем учебном заведении.

Ключевые слова: информационно-обучающая среда, электронная среда, дидактический ресурс, самостоятельная работа.

Nagrybelna I. A. Didactic resources of the electronic environment in the organization of an independent work of future primary school teachers.

In the article the scientific and methodical potential of the didactic resource of electronic environment has been analyzed. Its role in the organization of an independent work of future primary school teachers has been emphasized; the essence of the definitions related to the e-learning environment in a modern higher educational institution is defined.

Key words: e-learning environment, electronic environment, didactic resource, independent work. 
Світові тенденції глобалізації, інтеграції та інформатизації суспільства, орієнтація України на входження до європейського освітнього простору визначають актуальні пріоритети розвитку вітчизняної освіти. На сучасному етапі розвитку вищої освіти першочерговим $\epsilon$ пошук підходів до вдосконалення самостійної роботи студентів, що виявляється в застосуванні новітніх технологій навчання, дозволяє забезпечити ефективну організацію самостійної роботи. Це зумовлює формування вмінь майбутніх учителів початкових класів розв’язувати дослідницькі завдання упродовж періоду здобування професійної освіти і майбутньої професійної діяльності.

Усвідомлення означених чинників вплинуло на постановку проблеми, що полягає в аналізі дидактичного ресурсу електронного середовища в організації самостійної роботи майбутніх учителів початкових класів. Аналізована проблема має зв'язок із науковими завданнями, що реалізуються у фаховій підготовці студентів педагогічних факультетів до навчання української мови засобом самостійної роботи.

Актуальність обраної проблеми зумовлена тим, що в контексті реформаційних процесів важливого значення набуває вдосконалення системи організації самостійної роботи студентів до навчання мови, і це відіграє особливу роль у підготовці майбутніх учителів початкових класів, розвитку їхніх здібностей і готовності до фахового самовдосконалення.

Аналіз останніх досліджень та публікацій свідчить, що проблема самостійної роботи досліджувалася науковцями різнопланово. Це й дозволило розв'язати низку важливих завдань:

- обгрунтування методологічних засад сучасних освітніх парадигм, що визначають провідні напрями самостійної роботи студентів (О. Базалук, І. Зязюн, В.Кремень, В. Огнев'юкта ін.);

- визначення наукових засад самостійної роботи (А. Алексюк, С. Архангельський, Ю. Бабанський, В. Бондар, В. Буряк, О. Вербицький, Г. Гецов, В. Мороз та ін.);

- 3'ясування ролі самостійної роботи в процесі розвитку творчих здібностей студентів (I. Богданова, С. Гайдай, Л. Журавська, І. Копотюк， В. Король， В. Мороз， Л. Осінова, Р. Пріма, Л. Разумова та ін.);

- обгрунтування лінгвістичних та лінгводидактичних засад самостійної роботи у професійній підготовці вчителів загалом і початкової школи зокрема (М. Бондаренко, М. Вашуленко, Н. Голуб, О. Горошкіна, Т. Донченко, І. Дроздова, М. Пентилюк, О. Попова, I. Потапова, Т. Потоцька, М. Починкова, М. Соловейчик, М. Чабайовська та ін.);

- необхідність підвищення якості самостійного навчання в умовах інформаційного середовища (Н. Бойко,Г. Козлакова, Л. Пєтухова, М. Солдатенко, О. Шиман, С. Яшанов та ін.) $[2 ; 4$, с. $177-191 ; 6$, с. $21-24 ; 7]$.

Спираючись на погляди науковців й ураховуючи вимоги до підготовки сучасного фахівця початкової школи, ми з'ясували, що виокремлюється низка нерозв'язаних раніше питань досліджуваної проблеми. Так, не була предметом спеціального дослідження проблема визначення лінгводидактичних умов організації самостійної роботи, виокремлення й реалізації сучасних підходів до самостійної роботи майбутніх учителів початкових класів у контексті нових завдань університетської освіти.

У зв'язку з цим вбачаємо метою статmі проаналізувати роль дидактичного ресурсу електронного середовища в організації самостійної роботи майбутніх учителів початкових класів.

Останнім часом у педагогіці набули наукової легітимності дефініції, що первинно застосовувалися в галузі інформатики: «інформаційне середовище», «інформаційно- 
навчальне середовище», «інформаційно-освітній простір», «інформаційно-освітнє середовище», «е-середовище». Український педагогічний словник» пропонує таке тлумачення: «інформаційно-навчальне середовище»- це сукупність умов, які сприяють виникненню й розвитку процесів інформаційно-навчальної взаємодії між студентами, викладачем і засобами нових інформаційних технологій, а також формуванню пізнавальної активності студента за умови наповнення компонентів середовища (різні види навчального, демонстраційного обладнання, програмні засоби й системи, навчально-наочні посібники тощо) предметним змістом певного навчального курсу [3, с. 149-150].

Під середовищем розуміють оточення, яке складається з сукупності природних, матеріальних, соціальних чинників, які прямо чи безпосередньо впливають на людину. Середовище - це субстанція, яка, на відміну від порожнього, незаповненого простору (вакууму), має певні властивості, що впливають на здійснення взаємодії між об'єктами, «сутнісний зміст певної реальності»; те, що знаходиться між об'єктами і $є$ посередником між ними.

Середовище - це не просто низка стимулів, на які має реагувати людина; середовище має такі ознаки: 1) середовище не має фіксованих меж у просторі і часі; 2) середовище впливає на всі органи відчуття одночасно; 3) середовище надає не тільки головну, але й вторинну інформацію; 4) середовище завжди містить більше інформації, ніж ми здатні свідомо сприйняти і зрозуміти; 5) середовище сприймається у зв'язку 3 практичною діяльністю; сприйняття пов'язане $з$ діяльністю і навпаки; 6) будь-яке середовище поряд із фізичними i хімічними особливостями має психологічні і символічні значення; 7) навколишнє середовище впливає як єдине ціле [1].

Освітній потенціал середовища використовувався впродовж усієї історії людства. На особливій ролі середовища 3-поміж чинників, які впливають на формування особистості, наголошували Сократ, Платон, Аристотель. Як свічать праці дослідників з історії педагогіки, освітнє середовище навчальних закладів Середньовіччя підпорядковувалося жорсткій регламентації та правилам. Епоха Відродження актуалізувала античні ідеї формування особистості, яка б гармонійно поєднувала позитивні фізичні і духовні якості, і відтак відстоювала потребу у створенні відповідного освітнього середовища.

3 огляду на те, що інформаційно-освітній простір створюється певною мірою стихійно, без урахування потреб конкретної людини, а інформаційно-освітнє середовище штучно створюється людиною, тому користувачі одночасно пристосовуються до нього i прагнуть пристосувати його відповідно до своїх потреб. Загальновідомо, що інформаційне суспільство створює можливості для сталого розвитку лише тим, хто володіє інформаційною та інформативною культурою. Функція ж викладача полягає в тому, щоб допомогти студентові орієнтуватися в різнопланових, динамічних інформаційних потоках [5, с. 71-76]. Це зумовлює використання у навчально-виховному процесі сучасних мультимедійних засобів навчання, зокрема комп'ютерної техніки задля раціонального процесу формувань знань, умінь і навичок майбутніх учителів початкових класів, що останнім часом набуває міждисциплінарного характеру. Домінантою сучасної освіти стала інформатизація, тісно пов'язана $з$ поняттям «інформаційні технології навчання», які широко застосовуються в освітній діяльності й розробляються як відкрита система загальнопедагогічних, психологічних, дидактичних, методичних процедур взаємодії педагогів і студентів 3 урахуванням антропо- і техноресурсів, спрямованих на проектування і реалізацію змісту, методів, форм та інформаційних засобів навчання, що відповідають їхній меті, особливостям майбутньої діяльності та вимогам до професійно значущих якостей. На думку С. Сисоєвої, 
поняття «інформаційні технології навчання» доцільно розглядати як ефективне використання програмних i технічних засобів (кіно-, аудіо- i відео- засобів, комп'ютерів, телекомунікаційних мереж) для роботи з інформацією, що виявляються у реалізації особою управлінських функцій пошуку, аналізу, синтезу, узагальнення, технічного оброблення i передачі інформаційних потоків [8]. Кожний освітній заклад створює власне інформаційнонавчальне середовище, що водночас є предметом, засобом і ресурсом освітньої діяльності. Останнім часом активізувалися дослідження, предметом вивчення яких стало «дистанційне навчання» та «е-навчання» (електронне навчання) як найпоширеніший різновид дистанційного навчання в українських вишах.

Науковці переконують, що е-навчання - це інтерактивне навчання, під час якого навчальний матеріал доступний у діалоговому режимі, яке забезпечує автоматичний зворотний зв'язок з навчальною діяльністю студента. У дефініції «е-навчання» (переклад 3 англійської мови e-learning, electroniclearning - навчання 3 використанням електронних навчальних матеріалів) акцентовано на іншому, відмінному від традиційних паперових способові репрезентації навчальних матеріалів, можливості гіпершвидкого дистантного обміну інформацією між викладачем i студентом, між студентами, що притаманно інформаційним освітнім технологіям. Дещо в іншому ракурсі, з психологічних позицій, енавчання характеризує В. Хименець: як психологію, яка орієнтує «того, хто навчається на новий стиль освіти для життя і на освіту упродовж усього життя, технологію, яка розвиває вміння і навички для сталого життя і неперервного самовдосконалення» [9].

Нині е-навчання синтезує ознаки традиційного й дистанційного навчання. Дистанційне навчання дослідники вважають формою навчання, у процесі якої одержання освітніх послуг здійснюється на відстані без відвідування вищих навчальних закладів 3 використанням засобів інформаційних технологій.

Застосування інформаційно-комунікаційних технологій у вищих навчальних закладах дає змогу індивідуалізувати та диференціювати освітній процес, оскільки дозволяє студентові обрати оптимальну для нього освітню траєкторію, збільшити питому вагу самостійної роботи.

Упровадження інформаційно-навчального середовища, яке надає навчальнопізнавальній та самоосвітній діяльності студентів відкритості, гнучкості та мобільності, розширює діапазон використання та можливості вибору засобів залежно від цілей і завдань фахової підготовки майбутніх учителів початкових класів. Оптимізації самостійної роботи студентів сприяє розроблення відповідного навчально-методичного забезпечення, до якого відносимо:

- програми навчальних дисциплін;

- методичні рекомендації до вивчення дисциплін;

- лекційні матеріали, матеріали до практичних занять;

- матеріали для самостійної роботи;

- рекомендації до написання контрольно-модульних робіт, курсових, бакалаврських, магістерських робіт;

- матеріали для контролю знань, що можуть застосовуватись як студентом для самотестування, так і викладачем.

Отже, продуктивне функціонування електронного середовища $\epsilon$ ключовим показником інноваційності організаційно-педагогічної системи вищої школи. Застосування інформаційно-комунікаційних технологій сприяє перетворенню вищих навчальних закладів на осередки обміну інформацією, дослідницькі майданчики, центри формування фахових 
компетентностей студентів, а відтак і динамічному розвиткові вищої освіти України. У таких вишах створено всі умови для розроблення технології організації самостійної роботи майбутніх учителів початкових класів у системі фахової підготовки до навчання української мови.

У результаті проведеного дослідження можемо зробити такі висновки: ефективне функціонування інформаційно-навчального середовища забезпечує дотримання таких вимог:

- підвищення мотивації студентів до навчально-пізнавальної та самоосвітньої діяльності завдяки удосконаленню мотиваційного інструментарію;

- створення електронних навчально-методичних комплексів, доступних для кожного студента;

- своєчасне інформування та методичний супровід, що допомагає реалізувати поставлені завдання в межах інформаційно-навчального середовища;

- співпраця викладача і студента/студентів у системі «е-середовище»;

- забезпечення особистісно зорієнтованого підходу в підготовці майбутнього вчителя початкових класів;

- доступність і прозорість дидактичних матеріалів для студентів;

- унаочнення структурування навчального матеріалу;

- урізноманітнення форм взаємодії, співпраці та стимулювання професійноособистісного саморозвитку студентів;

- забезпечення оперативного зворотного зв'язку з академічною групою, підгрупами, 3 кожним студентом;

- оптимізація навчального часу (у тому числі для самостійної роботи);

- своєчасний і прозорий контроль викладача за результатами самостійної роботи студентів;

- підвищення дидактичного потенціалу індивідуальних навчально-дослідницьких та науково-дослідницьких завдань;

- проектування індивідуальної траєкторії навчання кожного студента;

- вдосконалення навчально-виховного процесу відповідно до вимог кредитномодульної системи навчання;

- спонукання як студента, так і викладача до систематизації знань, самооцінювання, самореалізації, самоорганізації, саморегуляції, самоактуалізації.

- інтеграція локального інформаційно-навчального середовища до європейського та світового освітнього співтовариства тощо.

Досліджувана проблема не вичерпується представленим матеріалом, оскільки має багатовекторне наукове спрямування. Отже, перспективою подальших розвідок у цьому напрямі вбачаємо аналіз ефективності конкретних видів самостійної роботи з курсів «Методика навчання української мови», «Сучасна українська мова 3 практикумом», що передбачають застосування електронного ресурсу.

\section{Література}

1. Большой энциклопедический словарь / под ред. А. М. Прохорова. - [2-е изд., перераб. и доп.]. - Москва: Большая рос. энцикл.; Санкт-Петербург : Норинт, 1998. - 1456 с. 2. Вашуленко М. С. Удосконалення змісту і методики навчання української мови в 1-4 кл. / Микола Семенович Вашуленко. - Київ : Рад. школа, 1991. - 110 с. 3. Гончаренко С. У. Український педагогічний словник / Семен Устимович Гончаренко. - Київ : Либідь, 1997. 376 с. 4. Зязюн Л. Нові тенденції у підготовці вчителів Франції / Л. Зязюн // Неперервна професійна освіта: теорія і практика. - 2002. - Вип. II. - С. 177-191. 5. Нагрибельна І. А. 
Удосконалення фахової підготовки майбутнього вчителя початкових класів засобом самостійної роботи / I. А. Нагрибельна // Sience Rise. - 2015. - № 3/1 (8). - C. 71-76.

6. Пентилюк М. I. Професійна підготовка студентів-філологів: засвоєння лінгводидактичної термінології / М. І. Пентилюк // Дивослово. - 2005. - №11. - С. 21-24. 7. Солдатенко М. М. Теоретико-методологічні основи розвитку самостійної пізнавальної діяльності майбутнього вчителя: автореф. на здобуття наук. ступеня доктора пед. наук: спец. 13.00.04 «Теорія i методика професійної освіти»/ М. М. Солдатенко. - Київ, 2007. - 47 с. 8. Сисоєва С. О. Нариси з історії розвитку педагогічної думки: [навч. посіб.] / С. О. Сисоєва, І. В. Соколова. Київ : Центр навчальної літератури, 2003. - 308 с. 9. Химинець В. В. Інноваційна освітня діяльність / Василь Васильович Химинець. - Ужгород : ЗІППО, 2007. - 364 с.

УДК 371.13:004(043.3)

Ірина Онищенко

\section{СУЧАСНІ ВИМОГИ ДО ПРОФЕСІЙНОЇ ПІДГОТОВКИ МАЙБУТНЬОГО ВЧИТЕЛЯ ПОЧАТКОВИХ КЛАСІВ В УМОВАХ ІНФОРМАТИЗАЦІЇ ОСВІТИ}

Онищенко І. В. Сучасні вимоги до професійної підготовки майбутнього вчителя початкових класів в умовах інформатизації освіти.

У статті з'ясовано особливості впливу інформатизації вищої педагогічної освіти на процес професійної підготовки майбутнього вчителя початкових класів. Визначено основні професійно значущі якості сучасного вчителя початкової школи. Обгрунтовано сучасні вимоги до професійної підготовки майбутнього вчителя початкових класів в умовах інформатизації освіти.

Ключові слова: інформатизація, інформатизація освіти, професійна підготовка, професійне становлення вчителя.

Онищенко И. В. Современные требования к профессиональной подготовке будущего учителя начальных классов в условиях информатизации образования.

В статье раскрыты особенности влияния информатизации высшего педагогического образования на процесс профессиональной подготовки будущего учителя начальных классов. Определены основные профессионально значимые качества современного учителя начальной школы. Обосновано современные требования к профессиональной подготовке будущего учителя начальных классов в условиях информатизации образования.

Ключевые слова: информатизация, информатизация образования, профессиональная подготовка, профессиональное становление учителя.

Onyshchenko I. V. Modern requirements to the professional training of the future primary school teacher in the process of education informatization.

The article deals with peculiarities of the influence of the higher pedagogical education informatization on the process of the professional training of the future primary school teacher. The main professional qualities of the modern primary school teacher have been determined. The current requirements to the professional training of the primary school teacher in the process of education informatization have been grounded.

Key words: informatization, education informational, professional training, the professional growth of the teacher. 